THE PRODUCTIVITY AND EFFICIENCY OF BORDER LEICESTER $\times$ CHEVIOT, FINN $\times$ BLACFACE AND EAST FRIESLAND $\times$ BLACKFACE PROLIFIC CROSS-BRED EWES FOR LAMB AND CARCASS MEAT PRODUCTION IN ENGLAND

W. M. Tempest, T. G. Boaz, R. Jones. - The University of Leeds, Department of Animal Physiology and Nutrition, U.K.

Experiments have been carried out over 8 years to investigate systems of lamb production designed to make the fullest use of grassland, based on high levels of prolificacy of the ewes and high annual stocking rates per hectare.

The results show that for suckled fat lamb production, both the Bovder Leicester/Cheviot and East Friesland/Blackface crosses possess the necessary attributes of prolificacy and high milk yield, but the smaller size of the latter enables higher output per hectare to be obtained. The Finn /Blackface cross, despite higher prolificacy and smaller size, are less efficient for suckled fat lamb production, but have merit for producing " store " lambs for subsequent winter fattening.

REPRODUCTION AND ADAPTATION ABILITIES OF EASTFRIESIAN SHEEP IN THE ČR

B. Cumlivski. - Research Institute of Animal Production Praha 1o-Uhrineves, CSSR.

During the years 1969-I975 the prolificity and adaptability of 42 sheep, I 4 rams and their offspring of Eastfriesian breed were followed. The sheep and rams were from GDR imported wbere they were kept in small numbres of $\mathrm{I}-5$ animals. In our country this animals were kept together with other sheep breeds in a herd of $180-45^{\circ}$ animals. The individual tupping occured: at an age of I6-I9 months from I August to 31 October of each year. No synchronisation checks. took place. The lambs were kept till to the age of 4 months with their mothers. The daily feed rations for the sheep: $2,470 \mathrm{~kg}$ dry matter, $0,155 \mathrm{~kg}$ digestible protein and I, $10 \mathrm{~kg}$ Ste; for the lambs: $1,824 \mathrm{~kg}$ dry matter, $0,158 \mathrm{~kg}$ digestible protein and $1,024 \mathrm{~kg}$ Ste.

Imported sheep: Average recurrence of oestrus till to the conception (I-V lambing) occured 2,39 times. 6r,7 per cent of sheep became pregnant. The prolificity of the tupped sheep. amounted to I28, I per cent. Exit of lambs 35,3 per cent.

Sheep born in our country: Average occurence of oestrus till to the conception (I-V lambing) occured I,06 times. 93,75 per cent of sheep became pregnant. The prolificity amounted to. I 43,3 per cent and the exit of lambs 2,2 per cent.

The adaptability of the imported Eastfriesian sheep to the herd breeding is fairly low, especially in the worse conditions in which case the efficiency and disease-resistance and thestate of health are reduced. If the Eastfriesian sheep and lambs were born and kept in a herd their adaptation and reproduction abilities and the state of health were considerably better.

The observation of the Easftriesian sheep will continue.

\title{
FINNISH LANDRACE \ BORDER LEICESTER RAMS AS SIRES OF CROSSBRED EWES
}

F. K. Deeble $\left(^{*}\right)$ and J. D. Barker (**). - (*) Agricultural Development and Advisory Service, Reading, U. K. (**) Animal Breeding Research Organisation, Edinburgh, U. K.

The use of Finnish Landrace /Border Leicester rams to produce crossbred ewes, in place of the more traditional ram breeds used for crossbreeding, has resulted in lambing percentages being increased by about 14 per cent and rearing percentages increased by about 16 per cent over four lamb crops. Although individual lamb weights have been reduced by 6 per cent at ten weeks, the weight of lamb produced per ewe mated was 6 per cent greater from the Finnish Landrace /Border Leicester crosses. These figures for increased lambing percentages and decreased individual lamb weights are about one half of the values found when purebred Finnish Landrace rams were used as alternative crossbreeding sires, and hence are not unexpected. The advantage in using Finnish Landrace/Border Leicester rams instead of pure Finnish Landrace rams lies in the easier management of the crossbred ewes and their lambs, because of the more easily handled lambing percentages and relatively heavier lambs.

The improvement in prolificacy from the Finnish Landrace /Border Leicester crosses occured in the $\mathrm{I}$ year old and 2 year old dams particularly but was less marked in the older ewes. Furthermore, the differences in ewe weights, prior to mating, between the Finnish Landrace /Border 
Leicester cross and native breed crosses widened as the animals became older. A study is underway at one Ministry of Agriculture, Fisheries and Food, Experimental Husbandry Farm to determine whether improved nutritional levels, from 6 months of age, will maintain the advantage in prolificacy thoughout life and arrest the widening of the differences in ewe body weights as the animals get older.

\section{Croissance ET VAleur boUCHÈre DES PRODUITS ISSUS DE CROISEMENT ENTRE bÉLIERS DE RACES PROLIFIQUES ET BREBIS locales ESPAGNOLES".}

M. Espejo Diaz, M. Mora Seco de Herrera, et L. Garcia Barreto. - Departamiento de Produccion Animal I.N.I.A., Badajoz, Espana.

La vitesse de croissance des agneaux Finnois $\times$ Aragonais élevés en Aragon (région N.-E.) et Romanov $\times$ Mérinos élevés en Extremadure (région S.-O.) effectuée dans des fermes privées a été comparée à celle des races pures respectives. De même on a fait des comparaisons dans une ferme expérimentale de croisements Romanov $\times$ Mérinos, Romanov $\times$ Manchega, Romanov $\times$ Avagonais avec des races pures en étudiant la croissance et les qualites bouchères des carcasses.

Dans tous les cas traités, les agneaux issus de croisement de races prolifiques et de races locales espagnoles ont montré une vitesse de croissance plus élevée que celle qui correspond aux races locales pures, ce qui doit être attribué à la très petite taille des brebis de races locales. La croissance de ces animaux croisés a été presque égale à celle des agneaux issus du croisement avec Ile de France.

La conformation des agneaux croisés Romanov a été la même ou légèrement supérieure à celle des animaux de race locale. L'état d'engraissement a été aussi supérieur avec les agneaux croisés.

\section{REPRODUCTIVE EFFICIENCY OF ICELAND SHEEP \\ II. Prolificacy and reproductive performance of adult ewes}

S. Hallgrimsson. - The Agricultural Society of Iceland, Reykjavik, Iceland.

A brief description is given on the fertility of the Iceland sheep. The aim of the breeding the last 20 years has been to increase the fertility. The average number of lambs weaned pr. ewe for the whole population has increased from 1,07 in $1950-54$ to 1,42 in 1975 . There are given examples of differences between districts.

From the Sheep Recording Associations there is taken an example of change in fertility through 20 years, from 1,04 lambs born in $1950-54$ to 1,76 lambs born in 1975 . Results from Io Sheep Recording Associations for the years 1974 and 1975 are given, showing the average of 0,9 up to 2,3 per cent of all ewes being barren and 1,1 og 3,9 per cent of all ewes having triplets.

Results of investigations on losses of lambs are referred, showing average losses of lambs from birth (including still-born) to weaning of 5,7 per cent.

Investigations on fertility of white and non-white ewes are showing higher fertility of the non-whites.

There are given some estimates of the heritability of fertility in Icelandic sheep, showing $h^{2}=0,13-0,2 \mathrm{I}$.

\section{Repeatability OF OVULATION RATE AND ITS RELATIONSHIP WITH LITTER SIZE IN FOUR SHEEP BREEDS}

\section{J. P. Hanrahan. - The Agricultural Institute, Belclare, Tuam, Co. Galway, Ireland.}

Data on the ovulation rate of mature ewes of the following breeds were analysed: Finnish Landrace $(F)$, Galway $(G)$, Fingalway $(F G)$ (Galway ewes $\times$ Finn rams) and High Fertility $(H F)$. Average ovulation rates were $3.8,1.6,2.3$ and 2.6 , respectively. The repeatability of ovulation rate was $0.66,0.15,0.15$ and 0.78 for the $F, G, F G$ and $H F$ ewes. The corresponding values for the repeatability of litter size were $0.07,0.20,0.06$ and 0.13 . The correlation between ovulation rate and average litter size at the three previous lambings was $0.00,0.08,0.1 \mathrm{r}$ and 0.35 for $F, G, F G$ and $H F$ ewes, respectively. Evidence was obtained for a quadratic relationship between ovulation rate and litter size and the data suggested the existence of an optimum ovulation rate. The heritability of ovulation rate was 0.35 fnr Finn ewes and hence selection should be affective. 